удК 908

\title{
A.А. Кононенко
}

\section{РЕВОЛЮЦИЯ 1917 ГОДА В ТЮМЕНИ ГЛАЗАМИ ОБЫВАТЕЛЯ}

\begin{abstract}
Рассматриваются вопросы истории Февральской буржуазно-демократической и Октябрьской большевистской революции в контексте истории уездного сибирского города Тюмени. В качестве приоритетов выбраны сюжеты, связанные с повседневными наблюдениями и оценками людей, попавших в непростую жизненную ситуацию. Сделана попытка создать эффект «включенности» читателя в события. Вряд ли стоит полагать, что в период революции произошел переход «от чужой к своей власти». Делается вывод, что интерес обычного горожанина не выходил за рамки будничной борьбы за выживание, а «героическими» эти события сделала их мифологизация второй половины 1920-1930-х гг.

Ключевые слова: революция 1917 года; Тюмень; продовольственная и личная безопасность; криминализация жизни; передел собственности и прав; борьба за выживание; Гражданская война.
\end{abstract}

Данная статья не претендует на все многообразие взглядов, эмоций и мнений, обусловленных индивидуальной и групповой дифференциацией горожан в период революции 1917 г. Предлагаемый читателю текст преследует цель показать революционные события в небольшом уездном городе, численность которого едва достигала 50 тыс. человек, глазами обывателей. Что они видели и что не замечали, что чувствовали, переживали и чего пытались забыть - в общем, все то, что лежит в основе коллективного опыта, основу которого составляли поступки современников.

Исследования такого рода должны не только опираться на архивные материалы и периодическую печать, но и учитывать такие факторы, как быт, уровень жизни, слухи, сплетни, знаковые события. Например, наводнение весны 1914 г., которое для современников было гораздо важнее, чем мировые известия, такие как убийство в Сараево эрцгерцога ФранцаФердинанда или покушение на убийство Г.Е. Распутина в Покровском. История почти бескровной Февральской революции, а затем и большевистской революции и созданной ею политической системы далеко не полна без отражения ее в судьбах людей на «микроуровне» - уровне захваченного ею врасплох «маленького человека» в российской глубинке.

В конце февраля 1917 г. в Тюмени ничто не предвещало будущих трагических событий. Неожиданно 1 марта по телеграфу приходит известие - царь отказался от престола за себя и своего сына, передав его брату Михаилу. Михаил отказывается царствовать. Утром 2 марта 1917 г., узнав из телеграфного сообщения об отречении монарха, местные жители и поднадзорные лица собрались на несанкционированный митинг в здании городской думы. Так как количество собравшихся оказалось значительно большим, чем могло вместить помещение думы (около 700 человек), было предложено перейти в помещение клуба приказчиков. Избранный тут же Временный исполнительный комитет послал своих представителей к начальнику местного гарнизона, уездному исправнику и помощнику начальника губернского жандармского управления. Офицеры гарнизона взяли отсрочку и предложили встретиться после 19 часов. Видимо, связавшись со штабом округа, к вечеру они определились и проинформировали о готовности поддержать революцию. Полицейский исправник И.И. Мельников и жандармский ротмистр В.М. Калмыков добровольно сдают оружие. Лишь начальник почтово- телеграфной конторы Г.С. Ерофеев, ссылаясь на военное время, отказывается выдать документацию и служебную переписку. Он отстранен от дел и отправлен под домашний арест. Народ воодушевлен. Оркестр исполняет «Марсельезу» и «Вы жертвами пали в борьбе роковой». 5 марта 1917 г. губернатор Н.А. Ордовский-Танаевский призвал население к спокойствию и сохранению личной и имущественной безопасности, но на следующий день Тобольская городская дума отказала ему в доверии за связь с «темными силами самодержавия» и отправила в отставку. В тот же день в Тюмени солдатами был проведен обыск в хозяйстве бывшего игумена Мартемиана в монастыре и в доме еще одного друга Г.Е. Распутина - сундучника Д.Д. Стряпчего. 10 марта состоялся массовый митинг на Базарной площади. Все выступающие говорили о поддержке нового строя, проклинали голштинскую династию, помещали на одежду красные банты, славили председателя Государственной думы М.В. Родзянко. Революция тюменцами была признана. Пожалуй, единственным человеком, выступившим в защиту Романовых в Тюмени, был священник Знаменского собора о. Владимир (Хлынов) [1]. В марте 1917 г. во время службы в проповеди он поддержал свергнутого императора, был подвергнут критике, ему запретили службу и позднее перевели в Тобольск. Таким образом, как только прежняя власть в столице ушла в отставку, произошел беспрецедентный распад властных структур в провинции. Губернатор, органы внутренних дел и государственной безопасности без какого-либо сопротивления отрешились от своих обязанностей, а некоторые представители этих структур с воодушевлением перешли на сторону новой власти.

Февральско-мартовский переворот в Петрограде в значительной степени изменил жизнь в Тюмени. Приметой времени стали многочисленные собрания, митинги, демонстрации, участники которых распевали «Марсельезу», «Отречемся от старого мира» и носили по улицам портреты М.В. Родзянко, увитые красными лентами. Курьезный случай произошел во время проведения первой демонстрации в поддержку Временного правительства, когда колонны горожан двинулись по центральной улице к зданию городской управы. Из дома купца Брюханова на демонстрантов полетели стекла со второго этажа. «Оказывается, стекла были разбиты впавшим в помешательство лицом, много пострадавшим в дни первой русской рево- 
люции, у которого радостное известие о свободе вызвало крайне повышенное болезненное настроение. Больной был отвезен в городскую больницу» [2].

Изменения коснулись не только общественнополитической сферы, но и культурной жизни. В городе действовали три кинотеатра - «Гигант», «Палас» и «Вольдемар», в которых демонстрировали слезливые мелодрамы и спектакли с весьма неприхотливыми названиями «Женитьба Адемара», «Умирающая роза», «Борьба за счастье», «Любовь императрицы» или заявленная как жуткая драма в пяти частях «Месть падшей». Любопытно, что целью одной из мелодрам - «Любовь императрицы» - было стремление показать «психологию настоящего времени», а действующими персонажами выступали бывшая царская семья, ее окружение, в том числе Г.Е. Распутин. Роли бывшего временщика последних Романовых уделялось большое внимание на страницах центральных и тюменских газет. И это, по-видимому, не случайно. У сильной власти постоянно находятся «подпорки», стабилизирующие ее положение, у слабеющего правителя, напротив, неизбежно появляется «теневой двойник», сбивающий его сакральную ауру. Репутацию Николая II подпортили Распутин и императрица, причем степень их влияния не имела значения.

Приметой нового времени стало огромное количество анонимных писем, поступавших в редакции газет. Различные «доброхоты» уверяли журналистов в обнаружении то одного, то другого тайного сторонника бывшего режима, требовали опубликовать имена секретных сотрудников царской охранки. В настоящий авантюрный роман, привлекший внимание читающей общественности, превратилась переписка между В.И. Колокольниковым - председателем Временного исполнительного комитета г. Тюмени, и редактором газеты «Ермак» А.М. Афромеевым. Последний заявил, что горожане имеют право знать, кто входит во временный исполком, после чего был арестован и выслан в Сургутский уезд. После обжалования этого решения в Министерстве юстиции известный журналист вернулся в Тюмень и проинформировал население о злоупотреблениях новой городской власти. В результате 16 марта 1917 г. на площади состоялся митинг из 50-60 человек с требованиями «Долой Колокольникова!», «Просить Никольского!» (врач, бывший глава города). 21 марта В.И. Колокольников уступил свое место известному адвокату Н.И. Беседных. Ему же, опасаясь травли со стороны городского руководства, продал свою газету «Ермак» А.М. Афромеев.

Значительное место в жизни горожан отводилось вопросам продовольственной и личной безопасности. Основная проблема, с которой сталкивалось население, - нехватка то одного, то другого товара повседневного спроса. Например, значительный дискомфорт испытывали изголодавшиеся курильщики в связи с табачным голодом и стремительным ростом цен на папиросы. В июне 1917 г. 100 папирос стоили 25 руб., причем в одни руки отпускалось не более 10 . На глазах росла стоимость периодических изданий. Газеты в августе стоили 5 коп., в декабре - 10 коп. Но наибольшее озлобление населения вызывал рост цен на продукты питания. 31 марта 1917 г. выступили женщины, возмущенные стопроцентным повышением цен на молоко. Их поддержали солдаты и пристанские рабочие. 22 апреля 1917 г. горожанами в связи с повышением цены на мясо был объявлен бойкот торговцам - пришедшие на рынок домохозяйки вернулись домой с пустыми сумками. Испугавшись самочинных обысков и расправ со стороны солдат и горожан, 12 апреля на квартиру к председателю Временного исполнительного комитета Н.И. Беседных явился известный купец А.С. Колмаков и попросил арестовать его, чтобы укрыться в тюрьме от самосуда.

На протяжении лета-осени 1917 г. рост цен продолжался. Стоимость муки достигла 22 руб. за пуд. За фунт хлеба или кренделя продавцы требовали 12 коп. С 1 сентября чай стал продаваться по сахарным карточкам. Спекуляция карточками вызвала забастовку типографских и железнодорожных рабочих. С 1 января 1918 г. 1 фунт сахара-песка стал стоить 75 коп., рафинада - 80 коп. Сажень дров обходилась покупателю в 8 руб. 50 коп. при том, что, например, средняя пенсия составляла всего лишь 24 руб. 50 коп. Деньги стало нецелесообразно держать дома. Не случайно декабрь 1917 г. в Тюмени ознаменовался приливом вкладов в банки и сокращением мелких денежных знаков в обращении. Темпы инфляции с 1916 по 1919 г. можно проследить, обратившись к таблице, подготовленной обществом тюменских избирателей в мае 1919 г. [3].

\begin{tabular}{|l|c|c|}
\hline \multicolumn{1}{|c|}{$\begin{array}{c}\text { Наименование } \\
\text { товов }\end{array}$} & 1916 г. & 1919 г. \\
\hline $\begin{array}{l}\text { Пшеничная мука } \\
\text { пуд) }\end{array}$ & 1 руб. 50 коп. & 75 руб. \\
\hline Мясо (фунт) & 8 руб. 16 коп. & 220 руб. \\
\hline $\begin{array}{l}\text { Масло топленное } \\
\text { (фунт) }\end{array}$ & 33 руб. 50 коп. & 280 руб. \\
\hline $\begin{array}{l}\text { Масло конопляное } \\
\text { (ееверть) }\end{array}$ & 10 руб. 60 коп. & 220 руб. \\
\hline $\begin{array}{l}\text { Дрова березовые } \\
\text { (сажень) }\end{array}$ & 8 руб.50 коп. & 140 руб. \\
\hline
\end{tabular}

Война и революция спровоцировали дефицит не только продовольственных, но и промышленных товаров. Во всех мануфактурных магазинах были лишь шерстяные товары, шелк и тюль. Покупатели напрасно ходили из магазина в магазин. В магазинах Стахеевых 6 июня было получено 50-60 кусков материи, но ее разобрали за 3 часа, при этом два куска было украдено. 7 июня толпа женщин из 300 человек все утро осаждала магазин Стахеевых, требуя ситца. Уверения служащих ни к чему не привели. Женщины сели на прилавки, расположились на полу и стали ждать, что откуда-то «посыплется» мануфактура. Приказчики смиренно стояли за пустыми прилавками. Начали говорить, что товары спрятаны. Часть толпы отправилась в исполнительный комитет с требованием, чтобы в магазине был проведен обыск. Начиная с августа-сентября 1917 г. наблюдается дефицит мыла, причиной которого стало, по мнению респондентов, отсутствие правильного подвоза сырья и сокращение выработки на предприятиях. В качестве одной из мер для поставки мыла населению предлагалось его распространение поставить под контроль продовольственных комитетов [4].

Лозунг тех дней - «Берегись воров!». Кражи, грабежи, «наперсточники», подбрасывание «кукол» ста- 
ли явлением повседневным. 9 июля 1917 г. начальник гарнизона полковник В.Я. Дмитриев и секретарь редакции газеты «Свободное слово» кадет Ф.С. Гусев были избиты солдатами 35-го запасного полка. Военнослужащие тюменского гарнизона к лету 1917 г. совершенно распустились: в казармах пьянствовали, варили самогон, играли в карты. Наблюдалось всеобщее падение нравов. Не отставали от солдат, как правило, являвшихся застрельщиками нарушения общественного порядка, и отдельные горожане. Криминальная обстановка в городе с каждым днем все более осложнялась. В ночь на 31 августа 1917 г. в своем собственном доме был убит крупный предприниматель А.С. Колмаков. Особенно в плане криминала выделялись Сараи, где преступным промыслом занимались целые семейные династии. Стрельба, кражи, хулиганство, драки как результат социальной неустроенности и раньше были общественным злом города, теперь же они достигли катастрофических размеров. Наблюдается активный рост детского и юношеского алкоголизма и проституции. При этом недостатка в клиентах - горожанах, а также солдатах тюменского гарнизона и военнопленных стран германского блока - не было.

Революция, безусловно, отразилась не только на быте, но и на личной жизни горожан. При самодержавии женщине отводилась роль домохозяйки и матери, теперь тюменки стали активными участницами всех общественных и политических мероприятий. Ни одно городское массовое событие не обходилось без женщин, требовавших увеличения пенсий семьям военнослужащих или погибших, возмущавшихся разгулом цен на товары и услуги. С ликвидацией старорежимных запретов возросла роль женщины-хозяйки, что нашло отражение как в наследовании капиталов, так и в получении ею общегражданских свобод. Военные действия, миграция населения, постоянный приток беженцев, появление новых людей в городе разрушили патриархальный быт горожан. Оставшись за мужей, пребывавших на фронте, тюменские женщины после свержения самодержавия превратились во внушительную общественную силу, они активно занимались трудом - рукоделием, торговлей, преподаванием, участием в различных творческих и профессиональных союзах, зарабатывали сдачей жилья в наем, работали в сфере услуг. В результате необратимых общественных процессов в 1917 г. произошло разрушение традиционных патриархальных ценностей, сократилась экономическая зависимость женщин в семье, они стали более активными, предприимчивыми и самостоятельными, увеличился их вклад в семейный бюджет. Этот процесс проходил на фоне ликвидации сословных границ и сословных ценностей. В связи с заполнением города солдатами - молодыми, здоровыми людьми, поставленными на бессемейное положение, летучие браки делаются законом жизни.

При знакомстве с материалами, позволяющими реконструировать события 1917-1918 гг. в Тюмени, складывается впечатление, что большевистская революция в Петрограде оценивалась тюменцами всего лишь как смена одного временного правительства другим. Если события февраля-марта 1917 г. действи- тельно произвели серьезную переоценку традиционного уклада жизни населения России, жизни без царя, то поздняя осень 1917 - зима 1918 г. для тюменцев была временем значительно более серым и невыразительным. Общее ухудшение общественно-политического и экономического климата в стране осенью 1917 г., безусловно, отразилось на жизни тюменцев. Основные мысли горожан стали обращаться к вопросам элементарного выживания. Развал городского хозяйства, катастрофическая ситуация с водоснабжением города, массовая вырубка лесов, расцвет уголовной преступности, тягостные ощущения приближающегося голода обостряли общественную напряженность.

Так, 3 ноября 1917 г. дом купца В.Л. Жернакова был осажден толпой женщин и солдат, которые требовали «ревизии» купеческих запасов, изъятия чая, сахара и других продуктов. Не найдя излишков, толпа двинулась к следующему дому - купца Иванова [5]. В городе формируется военно-революционный комитет во главе с эсерами и меньшевиками. Параллельно возникает большевистская организация, основу которой составили бывшие фронтовики. 20 января 1918 г. в городском Совете произошло столкновение по вопросу власти и отношения к большевистской революции в Петрограде. Мнение меньшевиков отстаивал социал-демократ Н.Н. Авдеев. За предложенную им резолюцию, осуждающую большевиков, проголосовал 41 член Совета. За большевистскую резолюцию о взятии власти Советом, предложенную Г.П. Пермяковым, поступило 63 голоса [6]. Был сформирован новый исполком тюменского Совета рабочих и солдатских депутатов. Началось создание отряда тюменской Красной гвардии.

События в тюменском Совете происходили на фоне развала государственной власти в стране. Картина общественно-политической жизни в России была более чем странная: рабоче-крестьянское правительство в Петрограде называло себя временным, наряду с ним возникли Советы народных комиссаров в Москве, Курске, Архангельске, Екатеринбурге и более двух десятков «окраинных» небольшевистских правительств. Фактически старая российская государственность уже распалась, новая же еще не была создана. Всероссийское Учредительное собрание было разогнано большевиками и поддержавшими их левыми эсерами в ночь с 5 на 6 января 1918 г., а большевистская революция самоутверждалась под флагом мировой революции, претендуя на милленаристское начало. При общем ухудшении состояния жизни людей в стране и в городе это предопределило дальнейшее развитие событий.

В конфиденциальном докладе городского главы А.С. Флоринского продовольственной управе 19 января 1918 г. отмечалось:

«В настоящее, столь тревожное время является огромным опасением хранение вина и спирта в казенном винном складе. Охрана этого склада не может считаться надежной, а между тем нахождение в городе огромных запасов вина представляет большой соблазн для населения, низшие слои которого всегда могут при малейшем недосмотре или какой-либо слу- 
чайности воспользоваться этим вином, а так как самовольное взятие вина происходит в обстановке насилия и своевольства, то обычно, как это показывает опыт многих городов, разгром винных складов имеет многочисленные человеческие жертвы и сопровождается пожарами и разграблениями имущества граждан» [7].

На государственном складе скопилось 50 тыс. ведер спирта, незаметное уничтожение которого, по мнению главы Тюмени, было нереально. Население обязательно узнает об этом и постарается забрать спирт силой, как это было в соседнем городе Шадринске. А.С. Флоринский предложил оптимальное решение - перегнать спирт в вино (имеется в виду белое столовое вино - водка) и продать населению по карточкам из расчета по 1 бутылке на человека по 5 руб., направив полученные деньги на «повышение культурного уровня населения». С этой целью предлагалось открыть в разных районах города 6 магазинов. Однако запасов спирта оказалось несоизмеримо больше. Уездный комиссар В.П. Михайлов озвучил цифру - 2 млн бутылок, из которых 1,5 млн должны быть проданы населению (40 тысячам). Получалось по 37,5 бутылок каждому жителю Тюмени, в том числе младенцам. Часть водки решили продать населению Ялуторовского и Туринского уездов [Там же. Л. 9].

Несмотря на серые будни, развал в сфере жилищно-коммунального хозяйства, криминализацию не только окраин, но и центра города, жизнь в Тюмени даже тогда была более благополучной, чем в Центральной России. Пребывавшая в январе 1918 г. в городе баронесса С.К. Буксгевден отмечала высокую степень благосостояния, особенно в сравнении с Петроградом. При наличии денег Тюмень казалась страной обетованной. Домашний хлеб, сдобные булочки, икра, деликатесная уха из стерляди в местном ресторане по ценам, о которых в столице можно было лишь мечтать. Не менее хлебосольным был стол в деревенских трактирах по пути из Тюмени в Тобольск: огромное количество пельменей (вареных, с бульоном, жареных), которые традиционно подавались к обеду, гигантского размера осетры и с трудом размещавшиеся на столах тарелки с икрой и дикоросами (клюква, брусника, грибы, кедровые орехи) [8].

Относительное продуктовое изобилие существовало до марта 1918 г., когда в Тюмени была установлена советская власть. Докатившаяся до Сибири на штыках кронштадтских матросов большевистская революция (в город прибыли «Первый Северный морской карательный отряд», пермский, екатеринбургский и омские красногвардейские отряды) помогла местным большевикам сместить городскую Думу, собрать двухмиллионную контрибуцию, сформировать городской Совет народного хозяйства, изъять оружие, в том числе охотничье. Горожане были неприятно шокированы первым публичным расстрелом 14 уголовников, приведенных из городской тюрьмы, осуществленным по приказу «Военного комиссара Северного района Западной Сибири» М.А. Запкуса. Первые шаги советской власти были энергичными: введение рабочего контроля над производством, изъятие и распределение товаров, в первую очередь продовольствия, создание революционных трибуналов, демо- билизация военнослужащих старой армии, перенос губернского центра из Тобольска в Тюмень. Затем шли установление монополии на средства массовой информации, национализация предприятий, запрет частной торговли. В течение марта 1918 г. лишились собственности - кинотеатров «Гигант», «Био», «Вольдемар» и «Палас» - их владельцы И.С. Шустер, С.С. Шустер, М.А. Брюханов и А.Д. Ерофеева. Одной из форм борьбы с буржуазией было принудительное приобщение ее к физическому труду. Самым богатым людям города выдавались метлы, лопаты, и под присмотром красногвардейцев они отправлялись на уборку улиц и мощение тротуаров на Громовской и Новой улицах.

Тем не менее складывается впечатление, что руководство города в лице Н.М. Немцова, В.М. Кармашова, А.В. Неверова занималось лишь распределением произведенных ранее товаров и услуг, мало обращая внимание на восстановление производства, его рентабельность. Важнейшим источником пополнения городской казны были реквизиции и поборы, причем категория лиц, подлежавших революционному налогообложению, ежедневно расширялась. Впоследствии, после падения советской власти, было установлено, что всего Совет собрал с буржуазии 1 млн 868 тыс. руб., которые были израсходованы следующим образом: на содержание ревтребунала - 65 тыс. 625 руб.; подотчетным лицам - 56 тыс. руб.; на содержание губисполкома15 тыс. 319 руб.; содержание штаба Красной гвардии и Красной армии - 113 тыс. руб.; крестьянскому отделу 500 тыс. руб.; Туринскому совдепу - 100 тыс. руб.; советским отрядам - 40 тыс. руб.; учебным заведениям 8 тыс. 847 руб.; на борьбу с контрреволюцией - 32 тыс. руб. [9].

Конец мая 1918 г. ознаменовался выступлением чехословацкого корпуса и началом полномасштабной Гражданской войны в Сибири. Уже в июне Тюмень оказалась на осадном положении: город был заполнен красноармейцами и матросами Балтийского флота. Особенно много было матросов, считавшихся тогда «красой и гордостью революции». Это были люди без правил. Они ходили без бушлатов, с открытой шеей и носили ленты на бескозырках длиной до пояса. По воспоминаниям С.К. Буксгевден, «матросы были в почете, поэтому их обнимали женщины с обеих сторон. Женшины большевиков любили наряжаться. Руки женщин украшали реквизированные кольца и браслеты. Но декрет о национализации женщин в Тюмени в силу не вступил» [8. С. 410].

Рынок в городе работал, но так как Совет установил фиксированные цены, продукты быстро исчезали. Руководители большевиков в очередях не стояли - реквизированные продукты доставляли им прямо в Совет. С.К. Буксгевден вспоминала, что лучшим способом не привлекать к себе внимание было ношение потрепаной одежды: «Мы выглядели как настоящие пролетарии». Запомнился один местный житель, щеголявший в костюме, видимо, сшитом его женой из штор темнокрасного цвета. Главным источником продуктов питания были продажа или обмен на рынке собственных вещей, которые остались от прежней жизни. Архаизация среды обитания сказалась и на сфере обеденных услуг. Рестораны и трактиры в Тюмени работали, но основны- 
ми посетителями были солдаты и матросы, которые заказывали без оплаты самые дорогие вина и коньяки, а вместо металлических приборов, давно похищенных, пользовались деревянными ложками и вилками.

Частные вклады граждан были давно заморожены, банки не работали. В городе практиковались аресты наиболее зажиточных горожан, за которых можно было получить с родственников выкуп. Арестованные обоего пола содержались совместно. До людей доходили ужасные слухи об имитации расстрелов. Однако, по утверждению очевидца, серийных казней не было. На улицах и рекламных тумбах развешивались телеграммы о боях с казаками и чехами. Новости были противоречивыми, и излишне болтливые горожане могли легко стать жертвой доносчиков, которые щедро оплачивались властью. Слуги как класс давно исчезли. Если кто-то был недоволен своим работодателем, он угрожал донести на него в Совет и требовал прибавки к зарплате. Людей арестовывали по малейшему обвинению.

К середине июля 1918 г. чехословацкий корпус занял Ялуторовск, бои приблизились непосредственно к Тюмени. С целью взбодрить население большевики устраивали для трудящихся общественные балы, особенно после получения известий о поражениях на фронтах. Важное место в идеологической обработке населения занимали похороны красноармейцев, погибших в боях с Сибирской народной армией. Памятник Борцам революции на месте бывшего их захоронения и сегодня является одним из знаковых мест Тюмени. Сама похоронная процессия растянулась от железнодорожного вокзала до площади. Убитых оказалось вдвое больше, чем Совет подготовил гробов, поэтому комиссары реквизировали все готовые, в том числе предназначенные для женщин. Яркие бело-розовые «раковины» и красные гробы оказались меньшего размера и произвели на окружающих ужасное впечатление, так как из них торчали руки и ноги, когда их везли по улицам [8. С. 421]. Непросохшая краска оставляла на руках красные кровавые следы. Руководители процессии потребовали от горожан принять участие в мероприятии - нести своих мертвых товарищей. Желающих, однако, не нашлось. Звучали революционные гимны «Марсельеза» и «Интернационал». «Один фанатик предложил на митинге памяти арестовать и расстрелять всех буржуев сначала в домах с четными номерами, а потом с нечетными, одной из улиц. Потом перейти к другой улице, пока население не наполнится священным страхом» [Там же].

Вечером 19 июля 1918 г. большевики, опасаясь окружения, покинули город, который в течении суток принадлежал мародерам. «Склады на железной дороге, на пристани, на предприятиях были открыты, и имущество, продовольствие растаскивались грабителями. Тюмень выглядела как после большого погрома. На улицах (не могли всего захватить) валялись ящики, бочки с рыбой, пачки, даже не выделанные шкуры, банки с вареньем» [10]. 20 июля 1918 г. в город вошли войска Сибирской народной армии. За четыре с небольшим месяца своего правления тюменские большевики вступили в конфликт со значительной частью населения города и уезда. Опираясь исключительно на рабочих и беднейшую часть крестьянства, они сумели противопоставить себе практически все слои городского населения и не смогли организовать серьезную оборону Тюмени от войск Временного Сибирского правительства.

Взгляд на город в исследовательской перспективе единства времени, места и действия позволяет выявить характерные для того периода практики организации пространства принуждения, а также восприятия, усвоения и реинтерпретации этих конструктов историческими акторами. В связи с отречением императора и сомнительными перспективами Временного правительства верховная власть в России оказалась в «подвешенном» состоянии, что привело к беспрецедентному распаду всех государственных структур в провинции. Март 1917 г. не способствовал формированию новых органов власти, а привел к ликвидации старых. Это было время хаоса, распада, разрухи, психозов при одновременном возникновении самых необычных массовых иллюзий. Для старой правящей и новой демократической элиты было характерно игнорирование жизненных приоритетов и интересов народных масс, даже интересов собственного самосохранения. Сибирский город, находясь во власти традиционализма, склонного решать проблемы на основе уравнительных переделов, стремился закрыться в своем локальном мире. Горожане вступали в диалоги, дополняемые насилием, прежде всего, на основе сохранившегося враждебного отношения к государству. Основная часть тюменцев была проникнута чувством умеренного утилитаризма. Создается впечатление, что большинство важнейших событий 1917-1918 гг., таких как разгон Учредительного собрания, заключение Брестского мира, принятие новой советской Конституции, смена власти в период Гражданской войны, прошли мимо сознания горожан. Интерес «обычного» горожанина не выходил за рамки будничный борьбы за выживание, а знаковыми эти события сделала их мифологизация второй половины 1920-1930-х гг.

\section{ЛИТЕРАТУРА}

1. Сбитнев А. Протоиерей В.А. Хлынов // Духовенство Тюменского района и г. Ялуторовска. 1907-1941 гг. Тобольск, 2008. С. 89-92.

2. Ермак (Тюмень). 1917. 13 марта.

3. Избиратель (Тюмень). 1919. № 1. 29 мая.

4. Государственный архив Тюменской области (далее- ГАТО). Ф. 277. Оп. 1. Д. 1. Л. 66.

5. Свободное слово (Тюмень). 1917. 7 ноября.

6. Государственный архив социально-политической истории Тюменской области (далее - ГАСПИТО). Ф. 1545. Оп. 1. Д. 49. Л. 59.

7. ГАТО. Ф. 180. Оп. 1. Д. 23. Л. 1.

8. Буксгевден С.К. Минувшее. Четырнадцать месяцев в Сибири во время революции. Декабрь 1917 - февраль 1919 // Жизнь и трагедия

Александры Федоровны, императрицы. М. : Лента Книга; Вече; Гриф, 2012. 800 с.

9. ГАСПИТО. Ф. 3894. Оп. 1. Д. 36. Л. 163-164.

10. Калугин Н.В. Мои воспоминания // Сибирский исторический журнал. (Тюмень) 2002. № 1. С. 63.

Статья представлена научной редакцией «История» 1 февраля 2017 г. 


\section{THE 1917 REVOLUTION IN TYUMEN IN A LAYMAN'S VIEW}

Vestnik Tomskogo gosudarstvennogo universiteta - Tomsk State University Journal, 2017, 417, 88-93. DOI: $10.17223 / 15617793 / 417 / 13$

Anatoly A. Kononenko, Tyumen State University (Tyumen, Russian Federation). E-mail: a-kononenko@yandex.ru

Keywords: revolution of 1917; Tyumen; food and personal security; criminalization of life; redistribution of property and rights; struggle for survival; Civil War.

The article deals with the history of the February bourgeois-democratic and the October Bolshevik revolutions in the context of the history of the provincial Siberian city Tyumen. The purpose of the work is to analyze the views, opinions and evaluations as well as the actions of the contemporaries of these events whose main intention was to survive in the political disorders and economic ruin. The sources are not only archives but also memories, rumors, gossip, speculation, stories related to public events, all that is called personal testimonies. The research methodology is based on an interdisciplinary approach to analyze the revolution through the prism of the history of everyday life, historical anthropology, gender history, the history of emotions as well as the experience concept which is the interpretation of active and passive experiences of an urban community. Subjects related to everyday observations and assessments of ordinary people caught in difficult life situations have been chosen as priorities. The author intentionally ignores the political or socio-economic component which is traditionally provided by official authorities regardless of their ideological orientation since they do not quite correctly reflect the essence and perception of the revolutionary events by ordinary people. The history of everyday life and subjectivity is limited to the world of ordinary people. It is based not so much on official documents but rather on personal correspondence, memoirs, rumors and evidence. The mood of people according to reports and their mood in real life are different things. The description of daily events made "from a bird's eye view" and with the help of official documents loses a quality important for the history of everyday life: it ceases to touch, loses the effect of indirect contact, of dangerous proximity. The article analyses the events from March 1917 to July 1918: dispersion of power, household difficulties and the redistribution of property rights, the change of power - everything that directly affected the everyday life of the district town. A steady decline in living standards which began in August 1914 and led to a humanitarian catastrophe of 1921 influenced the citizens' emotions more than the monarchy collapse, the collapse of state institutions, political community degradation, the establishment and the fall of the Soviet power, the Civil War in the region. The person in the revolution era was more concerned about food availability, an opportunity to get clothes, common and infectious diseases than paper decrees and orders. The late autumn of 1917 was a gray and inexpressive period and the Bolshevik revolution in Petrograd was estimated by Tyumen residents just as a change of one provisional government by another. The author has made an attempt to create the effect of "involvement" of the reader and to avoid the notorious "local conditions" which did not appear at a closer examination. It is hardly worth believing that there was a transition from "alien government to the native one" during the revolution. As a result, a conclusion has been made that the interest of an ordinary citizen did not go beyond everyday survival and these events became "heroic" only due to the mythologization of the second half of the 1920 s and the 1930s.

\section{REFERENCES}

1. Sbitnev, A. (2008) Dukhovenstvo Tyumenskogo rayona i g. Yalutorovska. 1907-1941 gg. [Clergy of Tyumen Oblast and Yalutorovsk. 1907-1941]. Tobolsk. pp. 89-92.

2. Ermak. (1917). 13 March.

3. Izbiratel'. (1919). 1. 29 May.

4. State Archive of Tyumen Oblast (GATO). Fund 277. List 1. File 1. Page 66. (In Russian).

5. Svobodnoe slovo. (1917). 7 November.

6. State Archive of Social and Political History of Tyumen Oblast (GASPITO). Fund 1545. List 1. File 49. Page 59. (In Russian).

7. State Archive of Tyumen Oblast (GATO). Fund 180. List 1. File 23. Page 1. (In Russian).

8. Buksgevden, S.K. (2012) Minuvshee. Chetyrnadtsat' mesyatsev v Sibiri vo vremya revolyutsii. Dekabr' 1917 - fevral' 1919 [The Past. Fourteen months in Siberia during the revolution. December 1917 - February 1919]. In: Zhizn' i tragediya Aleksandry Fedorovny, imperatritsy [Life and tragedy of Alexandra Feodorovna, the Empress]. Moscow: Lenta Kniga; Veche; Grif.

9. State Archive of Social and Political History of Tyumen Oblast (GASPITO). Fund 3894. List 1. File 36. Pages 163-164. (In Russian).

10. Kalugin, N.V. (2002) Moi vospominaniya [My memories]. Sibirskiy istoricheskiy zhurnal. 1.pp. 63. 